\title{
Effect of Various Pre-Treatments and Alternating Temperature on Seed Germination of Artemisia herba-alba Asso
}

\author{
Abdelmonaim Homrani-Bakali ${ }^{1}$ \\ ${ }^{1}$ National Institute of Agronomic Research of Morocco, Regional Center of Errachidia, Morocco \\ Correspondence: Abdelmonaim Homrani-Bakali, National Institute of Agronomic Research of Morocco, \\ Regional Center of Errachidia, Errachidia, Morocco, BP. 2 Errachida principale, Morocco. Tel: \\ 00212-66-015-7207. E-mail: homrani_bakali@yahoo.fr
}

\author{
Received: March 17, 2014 Accepted: October 13, 2014 Online Published: November 5, 2014 \\ doi:10.5539/jps.v4n1p12 URL: http://dx.doi.org/10.5539/jps.v4n1p12
}

\begin{abstract}
The present study was designed to determine the effect of alternating temperature regimes (R) and pre-treatments on the achenes germination of Artemisia herba-alba Asso, in order to provide information about germination requirements to be used for the rehabilitation programs. Four alternating temperature regimes with a day-night cycle $(16 / 8 \mathrm{~h})$ were applied R1: $\left(35-20{ }^{\circ} \mathrm{C}\right)$, R2: $\left(30-15{ }^{\circ} \mathrm{C}\right), \mathrm{R} 3:\left(25-10{ }^{\circ} \mathrm{C}\right)$ and R4: $\left(20-05{ }^{\circ} \mathrm{C}\right)$ and ten pre-treatments were tested for the best regime. This pre-treatments include the pre-soaking in cool water at two durations, pre-soaking in hot water for two durations, pre-soaking in sulphuric acid $(0.1 \mathrm{Mol} / 1)$ for two durations, pre-soaking in GA3 (Gibberellic acid) for four hours at three concentrations $\left(10^{-5} \mathrm{M}, 10^{-4} \mathrm{M}\right.$ and $\left.10^{-3} \mathrm{M}\right)$ and mechanical scarification with soft sandpaper. Temperature regimes affect significantly at the level 0.05 the final germination percentage and influence the germination rate. The R2 registered the best performances and the increase and the decrease of the temperature reduces the ability of seeds to germinate. Also, the application of the pre-treatments result in highly significant differences $(p<0.01)$ for the germination characteristics, basically the pre-soaking in cool water during $48 \mathrm{~h}$ that gave the best overall percentage of germination $(71 \%)$. The use of GA3 to promote germination was not significant as compared to control even at the highest concentration $\left(10^{-3}\right.$ $\mathrm{M})$.
\end{abstract}

Keywords: Artemisia herba-alba, germination, temperature regimes, pre-treatments

\section{Introduction}

Artemisia herba-alba Asso is an important pastoral species with high protein content (M. Houmani, Z. Houmani, \& Skoula, 2004; Boufennara, Lopez, Bousseboua, Bodas, \& Bouazza, 2012). It is considered one of the most promising species for the restoration of degraded arid pastoral ecosystems in Morocco (El Aich, 1992). This species is also considered as a natural way to fight against erosion and desertification (Benjilali \& Richard, 1980; Cerdà, 1997).

A. herba-alba (desert wormwood, white wormwood, "Arabic Shih") is a chamaeophyte steppic aromatic dwarf shrub (or small woody shrub) with many basal greenish-silver, erect and leafy stems (Ozenda, 1983). The Artemisia herba-alba Asso with homotypic synonyms of Artemisia aragonensis Lam. and Seriphidium herba-alba (Asso) is classified into the Asteraceae family, subfamily of Asteroideae, tribe of Anthemideae, genus: Artemisia L. and subgenus: Seriphidium (Torrell, Cerbah, Siljak-Yakovlev, \& Valles, 2003; Greuter, 2006). White Artemisia is a prominent western Irano-Turanian plant of North Africa steppes, South Western Europe (Mediterranean basin), Arabian Peninsula and Western Asia and extends into North Western Himalayas (Zohary, 1973; Ozenda, 1983). White Artemisia is widely distributed in Moroccan steppes from the semi arid bioclimatic zone to the Saharan zone and covers more than 5 million hectares (Benabid, 1991).

In spite of its exceptional resistance to drought and grazing (Ourcival, 1992; Guenaoui, Gorai, Smiti, \& Neffati, 2008), Artemisia herba-alba Asso is henceforth in regression in several regions of Morocco. During the last decades, continuous high grazing pressure, uncontrolled rain-fed barley cultivation, uprooting for fuel wood and drought resulted in a regression of rangeland steppes dominated by white wormwood (Mahyou, Tahri, Thomas, \& Bounejmate, 2001; Mahyou, Tychon, Balaghi, Mimouni, \& Paul, 2010).

The importance of this natural resource in Morocco and the rate of its degradation have prompted in the past a 
number of studies on its strategies of multiplication basically in foreign countries like Jordan (Al Charchafchi \& Jawad, 1982a; 1982b; Berkat, 1986; Al-Charchafchi, Redha, \& Kamel, 1987). Recent physiological studies have proved that white Artemisia achenes contain phytotoxic chemicals that prevent germination in unfavorable conditions. These chemicals or the phenolic compounds are toxic (allelopathic) for the germination of other species and might be involved also in an auto seed germination inhibition of $A$. herba-alba (Escudero, Albert, Pita, \& Garcia, 2000; Al-Charchafchi \& Al-Quadan, 2006; Modallal \& Al-Charchafchi, 2006). Finally, dry storage of seeds has been reported to increase germination by more than $90 \%$ (Al Charchafchi, 2006). All these investigations have discussed results based on the germinability (germination percentage) and some physiological aspects related to the dormancy of seeds, but the effect of alternating temperature regime and quantitative aspects like time, rate, homogeneity, and synchrony of germination must be considered during the germination process (Bewley \& Black, 1994; Ranal \& Santana, 2006). These characteristics are important for ecologists because it is possible to predict the degree of success of a species based on the capacity of their harvest seed to spread the germination through time, permitting the recruitment in the environment of some part of the seedlings formed (Ranal \& Santana, 2006).

Information of seed germination requirements and characteristics is therefore crucial for the restoration and the rehabilitation of rangeland by seed dispersal. The germination is a complex process that is controlled by several biological (species, seed viability, seed dormancy, seed size) and environmental (moisture availability, temperature, light intensity and duration) factors (Bewley \& Black, 1994). Most investigators working on the seed germination characteristics of some other Artemisia species have reported that light, temperature, chilling are dry storage (assuming that soil moisture is adequate) are some key factors to break dormancy and to achieve germination of Artemisia species (Meyer, Monsen, \& McArithur, 1990; Zheng et al., 2005a; Ronnenberg, Wesche, Pietsch, \& Hensen, 2007; Kumar, Gupta, Mali, Singh, \& Akash, 2013). Alternating and constant temperature have different effects on germination, alternating temperatures simulate the ambient temperature of different seasons and promote germination (Zheng et al., 2005b). In the dry areas, seed dormancy is common and some form of pretreatment is necessary to overcome physical and endogenous seed dormancy like presoaking in water, sand paper scarification, acid treatment, chemical treatments like presoaking in gibberellic acid (GA3), cold stratification etc. (C. Baskin \& M. Baskin, 1998). In this study, we aimed to relieve seed dormancy caused by internal and environmental factors and to enhance seed germination of $A$. herba-alba. For that reason, we analyzed in this work, the quantitative aspects of germination characteristics of white wormwood to some pre-treatments and under different alternating temperature regimes.

\section{Material and Methods}

\subsection{Achenes Collection and Storage}

Freshly mature achenes of $A$. herba-alba were collected from dry infructescences from natural populations of a resting site "Boutaâricht" in the Gourrama zone ( $32^{\circ} 17^{\prime} \mathrm{N}$ latitude, $004^{\circ} 08^{\prime} \mathrm{W}$ longitude and $1323 \mathrm{~m}$ elevation) located in the South East of Morocco. This region is characterized by an arid climate with a mean annual precipitation of $161.6 \mathrm{~mm}$ and a mean annual temperature of $16.5^{\circ} \mathrm{C}$. The seeds were collected during the end of February and the beginning of March 2008. Mature achenes were collected from a limited area of about $3 \mathrm{~km}^{2}$ to avoid heterogeneity. They were dry-stored in paper bags under ambient lab conditions of about $14{ }^{\circ} \mathrm{C}$ before the beginning of the test.

In the laboratory, infructescences were manually shaken to detach the achenes, and then the selection of achenes was done with the help of a microscope $45 \mathrm{x}$ to detect good seeds and to separate them from the floral organs.

\subsection{Germination Experiments}

Germination experiments were initiated in April 2008. The study of seed germination after pre-treatments is achieved in the laboratory conditions and inside an incubator according to the defined regime of temperatures. Temperature regimes were defined to simulate day-night average temperature of each season. The seeds have been incubated and maintained at an alternate temperature day-night cycle: R1: $\left(35-20{ }^{\circ} \mathrm{C}\right), \mathrm{R} 2:\left(30-15{ }^{\circ} \mathrm{C}\right), \mathrm{R} 3$ : $\left(25-10{ }^{\circ} \mathrm{C}\right)$ and $\mathrm{R} 4:\left(20-05^{\circ} \mathrm{C}\right)$.

Under alternating temperature regimes, 16 hours of light with higher temperature and 8 hours of dark with lower temperature conditions (photoperiod) were given to the seeds. Each temperature regime is replicated four times with 50 seeds in each replicate.

Experimentally manipulated treatments were as follows:

- $\quad$ Effect cool water (T1): Seeds of $A$. herba-alba were soaked separately for $\mathrm{T}_{1-1}: 24 \mathrm{~h}$ and $\mathrm{T}_{1-2}: 48 \mathrm{~h}$ ),

- Effect of hot water (T2): Seeds of $A$. herba-alba were soaked in boiling water at a constant temperature of 
$100{ }^{\circ} \mathrm{C}$ during $\mathrm{T}_{2-1}: 5$ minutes and $\mathrm{T}_{2-2}: 10$ minutes). After immersion, they were removed from the boiling water and left to cool on a table for about $15 \mathrm{~min}$.

- $\quad$ Sulphuric acid immersion (T3): Seeds of $A$. herba-alba were placed in a dilute sulphuric acid $\mathrm{H}_{2} \mathrm{SO}_{4}(98 \%)$ with a concentration of $0.1 \mathrm{Mol}$ of acid per liter during $\mathrm{T}_{3-1}: 15 \mathrm{~min}$ and $\mathrm{T}_{3-2}: 30 \mathrm{~min}$. The acid treated seeds were thoroughly washed with distilled water before the starting of germination.

- $\quad$ Effect of Gibberellic acid (GA3) (T4): Seeds of $A$. herba-alba were soaked in Gibberellic acid solutions with three different doses, $\mathrm{T}_{4-1}: 10^{-5} \mathrm{M}, \mathrm{T}_{4-2}: 10^{-4} \mathrm{M}$ and $\mathrm{T}_{4-3}: 10^{-3} \mathrm{M}$ during 4 hours.

- $\quad$ Effect of scarification of the seed coat by mechanical abrasion with soft sandpaper (T5).

Four glass Petri dishes $(150 \mathrm{~mm})$ were used for each treatment, 50 achenes per Petri dish were included. The achenes are placed above two layers of Whateman filter paper (two) and imbibided peridcally with demineralised water $(5 \mathrm{ml})$. To ensure no systematic effects due to position within the chamber, the replicates of Petri dishes were arranged according to a completely randomized block (four floors). These Petri dishes inside each floor are rearranged every 2 days

After applying the treatments, seeds were retrieved from solutions, rinsed thoroughly in running water, then rinsed with hydrochloric acid and again rinsed with distilled water and finally sown in sterilized Petri dishes.

Petri dishes were checked daily and germinated achenes were counted, and then removed every 10 days. Germination was defined as radical emergence (Bewley \& Black 1994, International Seed Testing Association ISTA, 1999).

\subsection{Germination Indices}

Nine germination indices were calculated to describe the process of germination: germinability (germination capacity) or final germination percentage (FGP), mean germination time (MGT), coefficient of variation of the germination time $(\mathrm{CVt})$, mean germination rate (MGR), germination rate index (GRI), coefficient of velocity of germination (CVG) (Speed of germination), mean daily germination (MDG) (number of seeds per day), germination value $(\mathrm{GV}), \mathrm{U}$ : uncertainty of germination and Synchrony of germination $(\mathrm{Z})$. All the germination parameters were calculated according to formulas given by Ranal and Santana (2006).

\subsection{Data Analysis}

The relative data to emergence and germination have been recorded for a period of 50 days. All data were analyzed using the SPSS program for windows Version 18.0. A one-way analysis of variance (ANOVA) and the averages of treatments are compared according to the method of Newman and Keuls to determine the significance of seed germination percentage under each treatment. Microsoft Office Excel 2007 software was used to calculate the different indices based on the work of Ranal et al. (2009).

\section{Results and Discussion}

\subsection{Results}

\subsubsection{Effects of Temperature Regime}

The statistical analysis of variance showed a significant effect of the alternating temperature regimes on the coefficient of variation of the germination time $(\mathrm{CVt})(\mathrm{p}<0.05)$ and a highly significant effect $(\mathrm{p}<0.01)$ on : the final germination percentage (FGP), the germination rate index (GRI), the mean daily germination (MDG), the uncertainty of germination $(\mathrm{U})$ and the synchrony of germination $(\mathrm{Z})$.

The regime R4: $20-05{ }^{\circ} \mathrm{C}$ resulted in the lowest FGP followed by the regime R3: $25-10{ }^{\circ} \mathrm{C}$, whereas the regime $\mathrm{R} 1: 35-20{ }^{\circ} \mathrm{C}$ presented a slower germination process as illustrated by the mean germination time (MGT) value. The MGT represents a measurement of the average length of time required for maximum seed germination (Bewley \& Black, 1994). The variability among the seeds in relation to the mean germination time for the regime R1 was higher compared to other treatments. The regime $\mathrm{R} 2: 30-15{ }^{\circ} \mathrm{C}$ was optimal in terms of germination capacity as seen from the values of the final germination percentage (FGP) and the germination rate index (GRI) (Table 1). The GRI combines the germination rate with the final germination percentage that is useful for comparisons when samples have equal germinabilities.

The germination rate also expressed by the coefficient of variation of the germination time $\left(\mathrm{CV}_{\mathrm{t}}\right)$ and the coefficient of velocity of germination $(\mathrm{CVG})$ explains precisely the velocity and the spreading of germination during the whole period of germination. The high value of this index provides information about the vigour of seeds (Ranal \& Santana, 2006). The mean germination rate was the best for the regime R3, thus the maximum speed of germination was at this regime (R3). Temperatures below and above the R3 decreased the speed of 
germination but did not halt it. To reach $50 \%$ of germination, the regime $\mathrm{R} 3$ required 11.3 days whereas the best regime R2 needs 13.1 days. Also, the R2 regime showed a higher coefficient of variation of the germination time $\left(\mathrm{CV}_{\mathrm{t}}\right)$, which indicates more irregular germination when compared to other regimes. But, the germination value (GV) which is an expression of speed and totality of germination, and their interaction (Brown \& Mayer, 1988) was clearly distinct for the regime R2. High values of the coefficient of velocity of germination (CVG) obtained mean higher seedling vigour of one sample, since samples with the same quantity of seeds germinated can present different values for this index (Ranal and Santana, 2006). Thus, emerged seeds obtained from the R3 regime are predicted to have best vigour as indicated by the values of the mean germination rate (MGR), and the coefficient of velocity of germination (CVG) compared to the other regimes (Table 1).

The characteristics of germination uniformity are defined by the measurement of the synchronization index $\mathrm{Z}$ and the uncertainty $(\mathrm{U})$ associated to the distribution of the relative frequency of germination (adaptation of the Shannon index). Low values of the $\mathrm{U}$ indicate more synchronized germination and more concentrated in time. Hence, germination in R2 regime was significantly spread in time compared to other regimes. The regime R3 was the most concentrated in time. The synchronization index $Z$ that is, the degree of germination overlapping (Then, $Z=1$ when the germination of all seeds occurs at the same time and $Z=0$ when at least two seeds could germinate, one at each time) presented greater homogeneity and higher synchrony of germination for R3 regime (lower value of $U$ and higher value of $Z$ ).

Table 1. Effect of the alternating temperature regimes on the germination characteristics of $A$. herba-alba

\begin{tabular}{lllll}
\hline $\begin{array}{l}\text { Temperature regimes } \\
\text { Germination parameters }\end{array}$ & $R 1:\left(35-20^{\circ} \mathrm{C}\right)$ & $R 2:\left(30-15^{\circ} \mathrm{C}\right)$ & $R 3:\left(25-10^{\circ} C\right)$ & $R 4:\left(20-05^{\circ} C\right)$ \\
\hline FGP $(\%)( \pm \mathrm{SE})$ & $17.50^{\mathrm{a}}( \pm 15.00)$ & $46.00^{\mathrm{b}}( \pm 4.32)$ & $23.00^{\mathrm{a}}( \pm 11.02)$ & $11.50^{\mathrm{a}}( \pm 4.43)$ \\
MGT $($ day $)( \pm \mathrm{SE})$ & $16.50^{\mathrm{a}}( \pm 4.25)$ & $13.09^{\mathrm{a}}( \pm 3.54)$ & $11.33^{\mathrm{a}}( \pm 1.94)$ & $12.92^{\mathrm{a}}( \pm 4.22)$ \\
$\mathrm{CV}_{\mathrm{t}}\left(\right.$ day $\left.^{-2}\right)( \pm \mathrm{SE})$ & $72.02^{\mathrm{b}}( \pm 10.42)$ & $81.10^{\mathrm{b}}( \pm 4.19)$ & $44.15^{\mathrm{a}}( \pm 10.21)$ & $63.73^{\mathrm{ab}}( \pm 21.76)$ \\
$\mathrm{MGR}^{-1}\left(\right.$ day $\left.^{-1}\right)( \pm \mathrm{SE})$ & $0.06^{\mathrm{a}}( \pm 0.02)$ & $0.08^{\mathrm{a}}( \pm 0.02)$ & $0.09^{\mathrm{a}}( \pm 0.01)$ & $0.08^{\mathrm{a}}( \pm 0.03)$ \\
GRI $($ day $)( \pm \mathrm{SE})$ & $1.07^{\mathrm{a}}( \pm 1.28)$ & $3.24^{\mathrm{b}}( \pm 0.27)$ & $1.26^{\mathrm{a}}( \pm 0.73)$ & $0.63^{\mathrm{a}}( \pm 0.22)$ \\
$\mathrm{CVG}(\%)( \pm \mathrm{SE})$ & $6.47^{\mathrm{a}}( \pm 2.13)$ & $8.07^{\mathrm{a}}( \pm 2.11)$ & $9.01^{\mathrm{a}}( \pm 1.48)$ & $8.46^{\mathrm{a}}( \pm 3.03)$ \\
GV $\left(\%{ }^{2}\right.$ day $\left.{ }^{-2}\right)( \pm \mathrm{SE})$ & $1.32^{\mathrm{ab}}( \pm 2.06)$ & $3.63^{\mathrm{b}}( \pm 2.36)$ & $2.22^{\mathrm{ab}}( \pm 1.78)$ & $0.33^{\mathrm{a}}( \pm 0.32)$ \\
$\mathrm{U}(\mathrm{bit})( \pm \mathrm{SE})$ & $2.33^{\mathrm{a}}( \pm 0.58)$ & $3.29^{\mathrm{b}}( \pm 0.23)$ & $2.09^{\mathrm{a}}( \pm 0.09)$ & $2.23^{\mathrm{a}}( \pm 0.44)$ \\
$\mathrm{Z}( \pm \mathrm{SE})$ & $0.08^{\mathrm{a}}( \pm 0.05)$ & $0.11^{\mathrm{ab}}( \pm 0.03)$ & $0.16^{\mathrm{b}}( \pm 0.06)$ & $0.03^{\mathrm{a}}( \pm 0.04)$
\end{tabular}

Numbers with different letters (a-b) are significantly different by Newman \& Keuls test at $\mathrm{p}<0.05$.

R1, R2, R3 and R4 are regimes of temperature; FGP: final germination percentage; MGT: mean germination time; $\mathrm{CV}_{\mathrm{t}}$ : coefficient of variation of the germination time; MGR: mean germination rate; GRI: germination rate index; CVG: coefficient of velocity of germination (Speed of germination); MDG: mean daily germination (number of seeds per day); GV: germination value; U: uncertainty of germination; Z: Synchrony of germination

\subsubsection{The Effect of Pre-Treatments}

The pre-treatments studied in the alternating temperature of the regime $\mathrm{R} 2: 30-15{ }^{\circ} \mathrm{C}$ had a significant effect on the germination characteristics of $A$. herba-alba seeds (Table 2). Seeds pre-soaked in cool water (T1) especially the pre-soaking in cool water during $48 \mathrm{~h}\left(\mathrm{~T}_{1-2}\right)$ gave the highest overall final germination percentage (FGP), germination rate index (GRI) and the germination value (GV) followed by the pre-soaking in cool water during $24 \mathrm{~h}\left(\mathrm{~T}_{1-2}\right)$. The germination capacity recorded for $\mathrm{T}_{1-2}$ was about $71 \%$ which is pretty good compared to the control. All the other pre-treatments were not significant $(\mathrm{p}<0.05)$ compared to the control. A. herba-alba treated with hot water affected negatively the germination capacity compared to the control as it resulted in a lower germination percentage (FGP), germination rate index (GRI) and germination value (GV).

The data showed that seeds pre-soaked in hot water $\left(\mathrm{T}_{2-2}\right)$ germinated faster and is predicted to have better seed vigour compared to the control and the other treatments as they are indicated by the values of the mean germination time (MGT), the coefficient of variation of the germination time $(\mathrm{CVt})$, the mean germination rate (MGR) and the coefficient of velocity of germination (CVG), they achieved their maximum germination within 
9.4 days. Whereas treated seeds with sulphuric acid presented the slower rate of germination and predicted to have the least vigour of seeds.

The interaction of the speed of germination and final germination was distinctly registered for seeds presoaked in cool water $T_{1-2}$.as it is illustrated by the germination value $(\mathrm{GV})$ (Table 2).

The treated seeds with hot water presented greater homogeneity and higher synchrony of germination (lower value of $U$ and higher value of $Z$ ) while the treated seeds with the sulphuric acid presented the least synchronized and more heterogeneous germination.

All concentrations applied of GA3 hormones had no effect on the germination parameters of A. herba-alba compared to the control.

Table 2. Effect of pre-treatments on germination characteristics of $A$. herba-alba

\begin{tabular}{|c|c|c|c|c|c|c|c|c|c|c|c|}
\hline & & $T_{1-1}$ & $T_{1-2}$ & $T_{2-1}$ & $T_{2-2}$ & $T_{3-1}$ & $T_{3-2}$ & $T_{4-1}$ & $T_{4-2}$ & $T_{4-3}$ & \\
\hline & & & & & $\begin{array}{l}19.00^{\mathrm{a}} \\
( \pm 6.83)\end{array}$ & & $\begin{array}{l}44.00^{\mathrm{b}} \\
( \pm 2.83)\end{array}$ & & & & \\
\hline & & & & & & & & & & & \\
\hline & & & & & & & & & & & \\
\hline & & & & & & & & & & & \\
\hline & & $63^{c}$ & $\begin{array}{l}4.24^{\mathrm{d}} \\
( \pm 0.08)\end{array}$ & $\begin{array}{l}1.16^{\mathrm{a}} \\
( \pm 0.24)\end{array}$ & $\begin{array}{l}1.22^{\mathrm{a}} \\
( \pm 0.33)\end{array}$ & $\begin{array}{l}1.24^{\mathrm{a}} \\
( \pm 0.07)\end{array}$ & $\begin{array}{l}1.23^{\mathrm{a}} \\
( \pm 0.04)\end{array}$ & $\begin{array}{l}2.16^{\mathrm{b}} \\
( \pm 0.49)\end{array}$ & $\begin{array}{l}2.22^{\mathrm{b}} \\
( \pm 0.39)\end{array}$ & & \\
\hline & & & $\begin{array}{l}7.20^{\mathrm{b}} \\
( \pm 0.84\end{array}$ & $\begin{array}{l}10.12^{\mathrm{c}} \\
( \pm 0.12)\end{array}$ & $\begin{array}{l}11.02^{\mathrm{c}} \\
( \pm 2.34)\end{array}$ & $\begin{array}{l}4.18^{\mathrm{a}} \\
( \pm 0.10)\end{array}$ & $\begin{array}{l}4.23^{\mathrm{a}} \\
( \pm 0.05)\end{array}$ & & $\begin{array}{l}5.47^{\mathrm{ab}} \\
( \pm 0.61)\end{array}$ & $\begin{array}{l}5.66 \\
( \pm 0\end{array}$ & \\
\hline & & $\begin{array}{l}6.81^{\mathrm{bc}} \\
( \pm 2.12)\end{array}$ & $\begin{array}{l}9.22^{\mathrm{c}} \\
( \pm 0.78\end{array}$ & $\begin{array}{l}1.28^{\mathrm{a}} \\
( \pm 0.58)\end{array}$ & $\begin{array}{l}1.04^{\mathrm{a}} \\
( \pm 0.81)\end{array}$ & $\begin{array}{l}7.67^{\mathrm{bc}} \\
( \pm 3.17)\end{array}$ & $\begin{array}{l}5.65^{\mathrm{abc}} \\
( \pm 2.10)\end{array}$ & $\begin{array}{l}6.18^{\mathrm{bc}} \\
( \pm 2.79)\end{array}$ & $\begin{array}{l}3.29 \mathrm{a}^{\mathrm{b}} \\
( \pm 1.21)\end{array}$ & $\begin{array}{l}4.03^{\mathrm{ab}} \\
( \pm 0.97)\end{array}$ & $\begin{array}{l}7.61^{\mathrm{bc}} \\
( \pm 4.00\end{array}$ \\
\hline & & $\begin{array}{l}3.84^{\mathrm{c}} \\
( \pm 0.05)\end{array}$ & $\begin{array}{l}3.96^{\mathrm{c}} \\
( \pm 0.13\end{array}$ & $\begin{array}{l}2.14^{\mathrm{a}} \\
( \pm 0.17)\end{array}$ & $\begin{array}{l}2.05^{\mathrm{a}} \\
( \pm 0.47)\end{array}$ & $\begin{array}{l}4.14^{\mathrm{c}} \\
( \pm 0.28)\end{array}$ & $\begin{array}{l}4.26^{\mathrm{c}} \\
( \pm 0.13)\end{array}$ & $\begin{array}{l}3.89^{\mathrm{c}} \\
( \pm 0.19)\end{array}$ & $\begin{array}{l}3.94^{\mathrm{c}} \\
( \pm 0.11)\end{array}$ & $\begin{array}{l}3.93^{\mathrm{c}} \\
( \pm 0.13)\end{array}$ & $\begin{array}{l}3.05^{\mathrm{b}} \\
( \pm 0.34\end{array}$ \\
\hline & & $0.06^{\mathrm{a}}$ & $\begin{array}{l}0.06^{\mathrm{a}} \\
( \pm 0.01\end{array}$ & $\begin{array}{l}0.14^{\mathrm{cd}} \\
( \pm 0.02)\end{array}$ & $\begin{array}{l}0.16^{\mathrm{d}} \\
( \pm 0.05)\end{array}$ & $\begin{array}{l}0.02^{\mathrm{a}} \\
( \pm 0.01)\end{array}$ & $\begin{array}{l}0.01^{\mathrm{a}} \\
( \pm 0.01)\end{array}$ & $\begin{array}{l}0.03^{\mathrm{a}} \\
( \pm 0.02)\end{array}$ & $\begin{array}{l}0.04^{\mathrm{a}} \\
( \pm 0.01)\end{array}$ & $\begin{array}{l}0.04^{\mathrm{a}} \\
( \pm 0.01)\end{array}$ & $\begin{array}{l}0.10^{\mathrm{b}} \\
( \pm 0.03\end{array}$ \\
\hline
\end{tabular}

Numbers with different letters (a, b, c, d) are significantly different by Newman \& Keuls test at $\mathrm{p}<0.05$.

$\mathrm{T}_{1-1}$ : presoaking in cool water during $24 \mathrm{~h} ; \mathrm{T}_{1-2}$ : presoaking in cool water during $48 \mathrm{~h} ; \mathrm{T}_{2-1}$ : presoaking in hot water during 5 minutes; $\mathrm{T}_{2-2}$ : presoaking in hot water during 10 minutes; $\mathrm{T}_{3-1}$ : presoaking in $\mathrm{H}_{2} \mathrm{SO}_{4}(0.1 \mathrm{~mol} / \mathrm{l})$ during $15 \mathrm{~min}$; $\mathrm{T}_{3-2}$ : presoaking in $\mathrm{H}_{2} \mathrm{SO}_{4}(0.1 \mathrm{~mol} / \mathrm{l})$ during $30 \mathrm{~min}$; T4-1: presoaking in Gibberellic acid (GA3) $10 \mathrm{mg} / 1$, T4-2: presoaking in GA3 $100 \mathrm{mg} / 1 ; \mathrm{T} 4-3$ : presoaking in GA3 $1000 \mathrm{mg} / \mathrm{l}$; T5: mechanical abrasion with soft sandpaper.

FGP: final germination percentage; MGT: mean germination time; $\mathrm{CV}_{\mathrm{t}}$ : coefficient of variation of the germination time; MGR: mean germination rate; GRI: germination rate index; CVG: coefficient of velocity of germination (Speed of germination); MDG: mean daily germination (number of seeds per day); GV: germination value; U: uncertainty of germination; $Z$ : Synchrony of germination

\subsection{Discussion}

\subsubsection{Effects of Temperature Regime}

Plants native to the arid steppes of Morocco are exposed to various levels of water stress. Temperature plays an important role in controlling the growth and development of plants. The effect of temperature on seed germination is quite complex because it affects each stage of germination process in a different way and is not independent of the other factors (C. C. Baskin \& J. M. Baskin, 1998). Alternating and constant temperature have different effects on germination (Ghersa, Arnold, \& Martinezghersa, 1992; Zheng et al., 2005b; Ronnenberg, Wesche, Pietsch, \& Hensen, 2007; Li, Jiang, Alamusa-Zhou, \& Oshida, 2012; Kumar et al., 2013). Alternating 
temperatures promote and improve germination; they are used to simulate the ambient temperature of different seasons (Zheng et al., 2005b).

The results presented in this report demonstrate that the temperature regime is an important factor that must be taken into account in order to program the convenient sowing period for A. herba-alba. Nerson (2007) claimed that temperature is the most significant factor in the germination process. Achenes of white Artemisia germinated within a wide alternating temperature window but the regime $\mathrm{R} 2\left(30-15^{\circ} \mathrm{C}\right)$ seems to have the most beneficial effect. Late spring (Mai) or the beginning of autumn (October) are relatively periods corresponding to regime R2, they should be the most suitable periods for sowing seeds of $A$. herba-alba, of course under suitable conditions of light and soil moisture. For vigorous seedling, our analysis demonstrated that seed of white wormwood should be sown at the beginning of spring (when the dispersal of seeds take place) period corresponding to the regime R3. When the humidity of soil is not restricted, the temperature of the soil plays a major role in the initiation of the germination of the seeds. The increase and decreases of temperature affect the faculty of germination of white Artemisia. Some report indicated that seed germination of some Artemisia species may be constrained by critical environmental factors, such as higher temperature and lower water availability (Tobe, Xiaoming, \& Omasa, 2005; Ronnenberg et al., 2007). Seed germination differs in the same family, genus and even for the same species (C. C. Baskin \& J. M. Baskin, 1998). That why our findings are more or less similar for example to the seed performances of Artemisia santolinifolia in $32 / 20{ }^{\circ} \mathrm{C}$ regime (Ronnenberg et al., 2007) and A. ordosica, A. sphaerocephala species in $30 / 20{ }^{\circ} \mathrm{C}$ regime (Zheng et al., 2005b; Tobe, Xhang, \& Omasa, 2006), but in contrast with other Artemisia species which they gave optimal results in the alternating temperature of $25 / 15^{\circ} \mathrm{C}$ (Huang \& Gutterman, 2000; Zheng et al., 2005a; Tobe et al., 2006) and 20/10 ${ }^{\circ} \mathrm{C}$ for A. arenaria (Tobe et al., 2006).

The germination rate was not affected by alternate temperature in contrast with the finding of Zheng et al. (2005b) on which the germination rate differs according to variation of alternating temperature (optimal in 30-20 $\left.{ }^{\circ} \mathrm{C}\right)$.

\subsubsection{Effect of Pre Treatment}

The hard testa of many desert shrubs has evolved to withstand unfavorable conditions such as heat caused by sunlight, severe drought and mechanical damage (Baskin \& Baskin, 1998; Silvertown, 1999). As a consequence, severe treatments are required to chance the testa permeability to water. Several pre-sowing treatments have been used to overcome hard testa imposed dormancy. There are a number of ways used to improve germination of seeds. Scarification by sulphuric acid is one of the effective and extensively used ways of germination enhancement. Also hot water treatment and sandpaper scarification are proven to be effective in improving seed germination for a lot of species. Gibberellic acid (GA3) is one of the most used phytohormone to overcome internal dormancy and to increase germination in several genera (Bewley \& Black, 1994). These treatments were used to make the testa permeable to water and to improve germination within a relatively short period of time. Unfortunately, in the present study, the germination responses of seeds to these pre-treatments were insignificant except the pre-soaking in cool water. Also the immersing seeds in a solution containing phytohormones (GA3) with different concentrations did not improve germination of $A$. herba-alba, because no significant difference in ultimate germinability compared to the control. These results explain that white Artemisia presents neither physical imposed dormancy by the testa nor physiological dormancy but it rather presents chemical dormancy as we will see later.

Seed germination study of white wormwood demonstrated that, even under favourable conditions for germination, only $71 \%$ of seeds ultimately germinated, following incubation temperature for as long as 50 days. This high percentage could be explained by the effect of pre-soaking in cool water during a long period on coat softening or maybe on the elimination of phytotoxins by water. Phenolic compounds were proved to play an important role in the auto inhibition of white Artemisia seeds and for other species (Al Charchafchi et al., 1987; Escudero et al., 2000; Al-Quadan \& Al-Charchafchi, 2006; Al-Quadan, Ibrahim, \& Al-Charchafchi, 2008). A. herba-alba presented in general an average germinability according to the pre-treatments applied, but there were some differences in the germination process (time and synchrony), which may be associated to the effect of pre-treatment. The medium average germinability of $A$. herba-alba seeds is in contrast to the finding of AlCharchafchi et al. (1987) as they obtained $100 \%$ of seed germination by removing the bracts (15\% germination with bracts). Thesis perhaps due to the dry storage of achenes not done in our case and that has been reported to increase seed germination by more than $90 \%$ according to Al Charchafchi (2006), or maybe to the genotype effect (Bewley \& Black, 1994), or due to the presence of other species close to A. herba-alba inducing allelopathic effect on Artemisia seed, or finally due to Artemisia fruit extracts that are (stored with the seed) involved in the inhibition of its own seeds germination (Atoum, Al-Charchafchi, \& Modallal, 2006; Pirzad et al., 
2010).

Following germination process as time, rate, homogeneity, and synchrony of germination is important, particularly in an ecological context, to estimate the degree of success of a species, as explained before (Ranal \& Santana, 2006). The germination process was relatively slower with mean germination times of at least 9.4 days. Germination and mean germination time observed for $A$. herba-alba seeds were lower than those obtained from other taxa in the same family (for example Mageiro, Assman \& Tressi, 2009). Differences in the germination time indicate diversity in the germination strategy of Artemisia individual seeds. Higher coefficient of variation of the germination time (CVt) and lower final germination percentage (FGP) observed in seeds of A. herba-alba individuals may reflect differences in imbibition and ability to break the testa and eliminate phytotoxins in seeds according to pre-treatments used. This variation may be viewed as a relative dormancy, considered as a way to spread germination over time. Sometimes the variation of velocity of germination is related to size of seeds (Busso, Mazzola, \& Perryman, 2005).

\section{Conclusion}

According to the results of this study, we can relatively improve the germination percentage of white Artemisia to $71 \%$ by using the pre-soaking in cool water during $48 \mathrm{~h}$ and to sow seeds in the spring season that was demonstrated according to the germination process to be the most convenient. Dormant seeds as for $A$. herba-alba may require chilling, dry storage after ripening and light as a germination stimulator which they will be the next investigation factors.

\section{Acknowledgments}

This paper is a part of the medium-term program of the research center of Errachidia, Morocco. It has benefited from the support of the Morocco Collaborative Grants Program (MCGP) funded by the International Center for Agricultural Research in the Dry Areas (ICARDA). I would like to thank Prof Abderrahim El Jebabra for her kind help to check the language.

\section{References}

Al-Charchafchi, F. M. R., \& Jawad, M. S. (1982a). Effect of Light, Temperature, and Storage Conditions and Seed Age On Germination of Desert Seed. I. Artemisia herba-alba. Journal of Agriculture and Water Resources Research, 1(1), 43-68.

Al-Charchafchi, F. M. R., \& Jawad, M. S. (1982b). Dormancy of some Desert Seed of Iraq. 1- Artemisia herba-alba, Journal of Research Agriculture Water Resources, 1(2), 5-14.

Al-Charchafchi, F. M. R., Redha, F. M. J., \& Kamel, W. M. (1987). Dormancy of Artemisia herba-alba Seeds in Relation to Endogenus Chemical Constituents. Journal Biological Science Research, 18(2), 1-12.

Al-Charchafchi, F. M. R. (2006). Dormancy in light sensitive Artemisia herba-alba seed in relation to germination oxygen uptake and water uptake. Mu'Tah Lil-Buhuth Wad-Dirasat, 21(1), 99-107.

Al-Charchafchi, F. M. R., \& Al-Quadan, F. (2006). Effect of Chlorogenic Acid on Germination and Seedling Growth, and on the Enzymes Activity Extracted from Artemisia herba alba Asso. Part I: Germination and Seedling Growth. Dirasat, Pure Sciences, 33(2), 168-175.

Al-Quadan, F., \& Al-Charchafchi, F. M. R. (2006). G6PDH and 6PGDH Activities of Artemisia herba-alba Seeds and Seedlings During Germination in Presence of Esculetin. Pak. J. Biol. Sci., 9(2), 210-213. http://dx.doi.org/10.3923/pjbs.2006.210.213

Al-Quadan, F., Ibrahim, A., \& Al-Charchafchi, F. M. R. (2008). Effect of Chlorogenic and Caffeic acids on activities and isoenzymes of G6PDH and 6PGDH of Artemisia herba-alba seeds germinated for one and three days in light and dark. Jordan Journal of Biological Science, 1(2), 85-88.

Atoum, M., Al-Charchafchi, F., \& Modallal, N. (2006). Biological activity and anti-mutagencity of water soluble phytotoxins from Artemisia herba-alba Asso. Pak. Jour. of Biological Science, 9(9), 1774-1778. http://dx.doi.org/10.3923/pjbs.2006.1774.1778

Baskin, C. C., \& Baskin, J. M. (1998). Seeds: Ecology, biogeography, and evolution of dormancy and germination. Academic, San Diego, California, USA.

Benabid, A. (1991). La préservation de la forêt au Maroc. In M. Rejdali \& V. H. Heywood (Eds.), Conservation des ressources végétales (pp. 97-104). Actes Editions. Rabat.

Benjilali, B., \& Richard, H. (1980). Étude de quelques peuplements d'armoise blanche du Maroc (Artemisia herb-alba Asso). Rivista Italiana e.p.p.o.s., 2, 69-74. 
Ben salem, H., Nefzaoui, A., \& Abdouli, H. (1994). Palatability of shrubs and fodder trees measured on sheep and camels. Methodological approach and preliminary results. In V. Papanastasis \& L. Stringi (Eds.), Fodder trees and shrubs (pp. 35-48). Cahiers Options Méditerranéennes 4. Palermo (Italy).

Berkat, O. (1986). Population structure, dynamics and regeneration of Artemisia herba-alba Asso (Unpublished doctoral dissertation). Inst. Agron. \& Vétér. Hassan II. Rabat.

Bewley, J. D., \& Black, M. (1994). Seeds. Physiology of development and germination (pp. 199-271). Plenum Press, London. http://dx.doi.org/10.1007/978-1-4899-1002-8_5

Boufennara, S., Lopez, S., Bousseboua, H., Bodas, R., \& Bouazza, L. (2012). Chemical composition and digestibility of some browse plant species collected from Algerian arid rangelands. Spanish Journal of Agricultural Research, 10(1), 88-98. http://dx.doi.org/10.5424/sjar/2012101-134-11

Brown, R. F., \& Mayer, D. G. (1988). Representing cumulative germination. The use of the Weibull function and other empirically derived curves. Ann. Bot., 57, 49-53.

Busso, C. A., Mazzola, M., \& Perryman, B. L. (2005). Seed germination and viability of Wyoming sagebrush in Northern Nevada. Interciencia, 30(10), 631-637.

Cerdà, A. (1997). Soil erosion after land abandonment in a semiarid environment of southeastern Spain. Arid Land Research and Management, 11(2), 163-176. http://dx.doi.org/10.1080/15324989709381469

El Aich, A. (1992). Fodder trees and shrubs in range and farming systems in North Africa. In A. Speedy \& P. L. Pugliese (Eds.), Legume Trees and Other Fodder Trees as Protein Sources for Livestock. (pp. 61-73). FAO Animal Production and Health, Paper 102. FAO, Rome.

Escudero, A., Albert, M. J., Pita, J. M., \& Garcia, F. (2000). Inhibitory effects of Artemisia herba-alba on the germination of the gypsophyte Helianthemum squamatum. Plant Ecology, 148, 71-80. http://dx.doi.org/10.1023/A:1009848215019

Ghersa, C. M., Arnold, R. L. B., \& Martinezghersa, M. A. (1992). The role of fluctuating temperatures in germination and establishment of Sorghum-halepense regulation of germination at increasing depths. Funct. Ecol., 6(4), 460-468. http://dx.doi.org/10.2307/2389284

Greuter, W. (2006). Compositae (pro parte majore). In W. Greuter \& E. Raab-Straube (Eds.). Compositae. Euro + Med Plantbase - the information resource for Euro-Mediterranean plant diversity. Retrieved from http://ww2.bgbm.org/euroPlusMed/PTaxonDetail.asp?NameId=117817\&PTRefFk=7000000

Guenaoui, C., Gorai, M., Smiti, S., \& Neffati, M. (2008). Biochemical and Physiological Changes in Artemisia herba-alba Plants under Water Stress Conditions. Middle-East Journal of Scientific Research, 3(3), 156-163.

Gupta, V. (2003). Seed germination and dormancy breaking techniques for indigenous medicinal and aromatic plants. Journal of Medicinal and Aromatic Plants Science, 25, 402-407.

Houmani, M., Houmani, Z., \& Skoula, M. (2004). Intérêt d'Artemisia herba-alba Asso dans l'alimentation du bétail des steppes algériennes. Acta Bot. Gallica, 151(2), 165-172. http://dx.doi.org/10.1080/12538078.2004.10516027

Huang, Z., \& Gutterman, Y. (2000). Comparison of germination strategies of Artemisia ordosica with its two congeners from deserts of China and Israel. Acta Botanica Sinica, 42(1), 71-80.

Kumar, B., Gupta, E., Mali, H., Singh, H. P., \& Akash, M. (2013). Constant and Alternating Temperature Effects on Seed Germination Potential in Artemisia annua L. Journal of Crop Improvement, 27, 636-642. http://dx.doi.org/10.1080/15427528.2013.832458

ISTA, (1999). International rules for seed testing. Seed science and Technology, 21, 288.

Li, X. H., Jiang, D. H., Alamusa-Zhou, Q. L., \& Oshida, T. (2012). Comparison of seed germination of four Artemisia species (Asteraceae) in northeastern Inner Mongolia, China. Journal of Arid Land, 4(1), 36-42. http://dx.doi.org/10.3724/SP.J.1227.2012.00036

Mageiro, E., Assman, J., \& Tressi, M. (2009). Efeito alelopático de Artemisa annua, L na germinaçao e desenvolvimiento inicial de plántulas de alface (Lactuca sativa, L) e leitero (Euphorbia heterophylla, L). $\begin{array}{lllll}\text { Revista Brasileira de } & \text { Plantas }\end{array}$ http://dx.doi.org/10.1590/S1516-05722009000300014

Mahyou, H., Tahri, M., Thomas, N., \& Bounejmate, M. (2001). Etude de la dégradation des parcours de la commune rurale de Aïn Béni Mathar à l'aide des systèmes d'information géographiques et de la télédétection. In M. Bounejmate \& M. El Mourid (Eds.), Compte rendu, atelier de Gestion Durable des Ressources Agropastorales (pp. 43-49). ICARDA, Alep, Syrie. 
Mahyou, H., Tychon, B., Balaghi, R., Mimouni, J., \& Paul, R. (2010). Désertification des parcours arides au Maroc. Tropicultura, 28(2), 107-114.

Meyer, S. E., Monsen, S. B., \& McArithur, E. D. (1990). Germination response of Artemisia tridentata (Asteraceae) to light and chill: patterns of between-population variation. Botanical Gazette, 151, 176-183. http://dx.doi.org/10.1086/337817

Modallal, N., \& Al-Charchafchi, F. M. R. (2006). Allelopathic effect of Artemisia herba-alba on germination and seedling growth of Anabasis setifera. Pak. J. Biol. Sci., 9, 1795-1798. http://dx.doi.org/10.3923/pjbs.2006.1795.1798

Nerson, H. (2007). Seed production and germinability of cucurbit crops. Seed Sci Biotechnol, 1, 1-10.

Önen H. (2006). The influence of temperature and light on seed germination of mugwort (Artemisia vulgaris L.). Journal of Plant Diseases and Protection, (Sp. Iss. 20), 393-399.

Ourcival, J. M. (1992). Réponse de deux chamaephytes de la Tunisie présaharienne à différentes contraintes et perturbations (p. 167). (Unpublished doctoral dissertation). USTL, Montpellier,

Ozenda, P. (1983). Flore du Sahara. Ed. CNRS, Paris, p. 622.

Pirzad, A., Ghasemian, V., Darvishzade, R., Sedghi, M., Hassani, A., \& Onofri, A. (2010). Allelopathy of sage and white wormwood on purslane germination and seedling growth. Notulae Scientia Biologica, 2(3), 91-95.

Ranal, M. A., \& Santana, D. G. (2006). How and why to measure the germination process? Revista Brasileira de Botânica, 29, 1-11. http://dx.doi.org/10.1590/S0100-84042006000100002

Ranal, M. A., Santana, D. G., Ferreira, W. R., \& Mendes-Rodrigues C. (2009). Calculating germination measurements and organizing spreadsheets. Revista Brasileira de Botânica, 32, 849-855. http://dx.doi.org/10.1590/S0100-84042009000400022

Ronnenberg, K., Wesche, K., Pietsch, M., \& Hensen, I. (2007). Seed germination of five mountain steppe species of Central Asia. J. Arid Environ., 71(4), 404-410. http://dx.doi.org/10.1016/j.jaridenv.2007.04.012

Silvertown, J. (1999). Seed ecology, dormancy, and germination: a modern synthesis from Baskin and Baskin. Am. J. Bot., 86(6), 903-905. http://dx.doi.org/10.2307/2656711

Tobe, K., Xiaoming, L., \& Omasa, K. (2005). Effects of irrigation on seedling emergence and seedling survival of a desert shrub Haloxylon ammodendron (Chenopodiaceae). Australian Journal of Botany, 53, 529-534. http://dx.doi.org/10.1071/BT04210

Tobe, K., Xhang, L., \& Omasa, K. (2006). Seed germination and seedling emergence of three Artemisia species (Asteraceae) inhabiting desert sand dunes in China. Seed Science Research, 16, 61-69. http://dx.doi.org/10.1079/SSR2005230

Torrell, M., Cerbah, M., Siljak-Yakovlev, S., \& Valles, J. (2003). Molecular cytogenetics of the genus Artemisia (Asteraceae, Anthemideae): fluorochrome banding and fluorescence in situ hybridization. I. Subgenus Seriphidium and related taxa. Plant Systematics and Evolution, 239(1-2), 141-153. http://dx.doi.org/10.1007/s00606-002-0259-0

Zheng, Y., Xie, Z., Gao, Y., Jiang, L., Xing, X., Shimizu, H., \& Rimmington, G. M. (2005a). Effects of light, temperature and water stress on germination of Artemisia sphaerocephala. Annals of Applied Biology, 146(3), 327-335. http://dx.doi.org/10.1111/j.1744-7348.2005.040039.x

Zheng, Y. R., Rimmington, G. M., Gao, Y., Jiang, L. H., Xing, X. R., An, P., ... Shimizu, H. (2005b). Germination characteristics of Artemisia ordosica (Asteraceae) in relation to ecological restoration in northern China. Canad. Journ. Bot., 83(8), 1021-1028. http://dx.doi.org/10.1111/j.1744-7348.2005.040039.x

Zohary, M. (1973). Geobotanical foundations of the Middle East, Vols. 1 and 2. Gustav-Fischer, Stuttgart, Germany.

\section{Copyrights}

Copyright for this article is retained by the author(s), with first publication rights granted to the journal.

This is an open-access article distributed under the terms and conditions of the Creative Commons Attribution license (http://creativecommons.org/licenses/by/3.0/). 